\title{
Evidence-based interventions to reduce tuberculosis stigma: a systematic review
}

\author{
N. Sommerland, ${ }^{*}$ E. Wouters, ${ }^{*}$ E. M. H. Mitchell, ${ }^{\dagger}$ M. Ngicho, ${ }^{\dagger}$ L. Redwood, ${ }^{\dagger}{ }^{\text {C. Masquillier, }}{ }^{*}$ \\ R. van Hoorn, ${ }^{\dagger}$ S. van den Hof, ${ }^{\dagger}$ A. Van $\mathrm{Rie}^{\ddagger}$
}

*Department of Sociology and Centre for Longitudinal and Life Course Studies, University of Antwerp, Antwerp, Belgium; ' ${ }^{\top}$ KNCV Tuberculosis Foundation, The Hague, The Netherlands; ${ }^{\ddagger}$ Global Health Institute, University of Antwerp, Antwerp, Belgium

S U M M AR Y

SETTING: While substantial progress is being made in tuberculosis (TB) control, the success of public health efforts is hampered by pervasive stigma.

OBJECTIVE: To perform a systematic literature review to assess the effectiveness of interventions aimed at reducing $\mathrm{TB}$ stigma in patients, health care workers, care givers and the general community.

DESIGN: Studies were eligible for inclusion if they evaluated interventions aimed at reducing TB stigma and were published between 1950 and 2015. We searched eight databases (PubMed, Cochrane Library, Ovid, Embase, PsycInfo, Sociological Abstracts, Cumulative Index to Nursing and Allied Health Literature, World Health Organization Latin American and Caribbean Health Sciences Literature), and complemented the searches by using the snowball strategy and by reviewing relevant grey literature.
RESULTS: Only seven studies were identified as providing quantitative $(n=4)$ or qualitative $(n=3)$ evidence of effectiveness in reducing TB stigma. Quality assessment of the studies was poor. Knowledge-shaping and attitude-changing interventions aimed at the public, patients and their families were effective in reducing anticipated stigma. Home visits and support groups were effective in reducing both anticipated and internalised stigma.

CONCLUSION: There is a dearth of reliable information on the effectiveness of TB stigma-reduction interventions. Knowledge-shaping, attitude-changing and patient-support interventions can be effective in reducing TB stigma, but more rigorous evaluations are needed. KEY WORDS : evaluation; TB; discrimination
ALTHOUGH TUBERCULOSIS (TB) is curable and preventable, it remains a significant public health problem. With 1.8 million TB deaths in 2015, TB remains one of the leading causes of death worldwide. $^{1,2}$ The stigma faced by people with $\mathrm{TB}$ is a major cause of the delay or failure to seek treatment, as well as poor adherence to treatment. ${ }^{3-7}$ Stigma is thus a major barrier to eliminating TB. Moreover, the social relationships of people with $\mathrm{TB}$ are often negatively affected by community members and care givers, who may be reluctant to socialise or be associated with them. ${ }^{3,4}$ Negative stereotypes have connected TB with concepts such as immorality, poverty, frailty, hedonism, effeminacy and selfdestruction. ${ }^{3,5}$ As stigma negatively impacts the physical and social consequences of $\mathrm{TB}$, there is a need to reduce it effectively. ${ }^{6}$

Through a systematic literature review, we aim to assess the effectiveness of interventions aimed at reducing TB stigma in patients, health care workers (HCWs), care givers and the general community.

\section{METHODS}

By applying the Cochrane Search Strategy, we conducted a systematic and comprehensive literature review to identify and assess the effectiveness of evaluated interventions aimed at reducing TB stigma. ${ }^{8}$ As different types of stigma have different outcomes and effects, three types were conceptualised to aid this synthesis: anticipated, internalised and enacted stigma. ${ }^{7}$

'Anticipated stigma' refers to the imagining of the prejudices, discrimination and negative attitudes that a person would experience if he/she was to have a 'tainted identity'. 'Internalised stigma' is the degree to which someone is believed to possess the negative traits assumed to be associated with the stigmatised characteristic. 'Enacted stigma' refers to the lived

Correspondence to: Nina Sommerland, Department of Sociology and Centre for Longitudinal and Life Course Studies, University of Antwerp, SZ 210, 2000 Antwerp, Belgium. e-mail: nina.sommerland@uantwerpen.be

Article submitted 19 October 2016. Final version accepted 7 February 2017. 


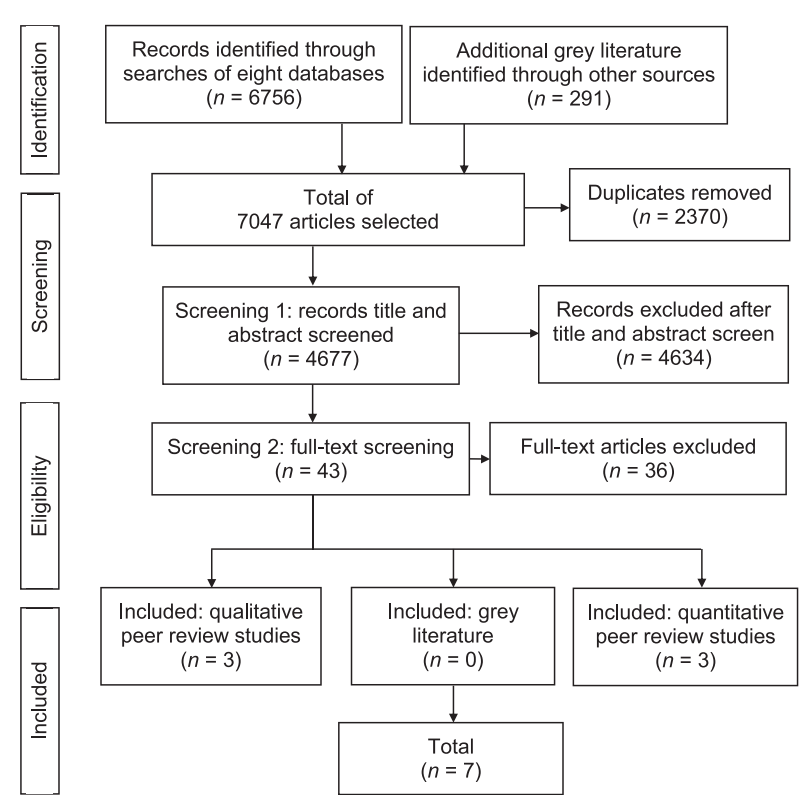

Figure PRISMA flowchart. PRISMA = Preferred Reporting Items for Systematic Reviews and Meta-Analyses.

experiences of mistreatment and discrimination. ${ }^{9}$ We used terminology from different behaviour-change methods to describe and synthesise the interventions.

Eight databases (PubMed, Cochrane Library, Ovid, Embase, PsycInfo, Sociological Abstracts, Cumulative Index to Nursing and Allied Health Literature, World Health Organization [WHO] Latin American and Caribbean Health Sciences Literature) were searched for peer-reviewed literature published between 1950 and 2015 in English, Spanish, Portuguese, German, Dutch and French. 'Grey literature' was obtained from the WHO database, the Stop TB partnership internet website, the US Centers for Disease Control and Prevention TB resource database, KNCV Tuberculosis Foundation archives, and abstracts from the International Union Against Tuberculosis and Lung Disease's annual World Conference on Lung Health between 2008 and 2015. The reference lists of relevant articles were searched to find additional studies. As qualitative studies are often not found using conventional search methods, ${ }^{10}$ the 'snowball strategy' and citation tracking were also applied.

\section{Selection criteria}

Included study types were randomised controlled trials, quasi-experimental studies with longitudinal or cross-sectional designs, qualitative, and mixed-methods studies. ${ }^{11}$ Studies focused on three types of participants: 1) the general public, 2) people with $\mathrm{TB}$, and 3) care givers, including HCWs.

\section{Search strategy and screening}

To perform a thorough search, a wide range of search terms was included: Title: tubercul* or 'lung tuber- culosis' or 'pulmonary consumption' or 'consumption, pulmonary' or 'TB' AND Title: stigma" or discrimin* or barrier* or attitud* or discredit* or self-efficacy or 'self-concept' or discrimina* or inequ* or prejudic* or stereotyp* or 'social percept*' or 'social isolat", or 'social inclus*' or disclos* or 'patient-centered' or shame or perspect" or percept" or 'patient satisfact"' or depress" or quality or fear or inter-personal or psychosocial or default or adher* or psycholog* or self-harm or identity or emotion* or communicat" or 'social suppor*' or 'patient suppor*' or culture*. Titles and abstracts in the abstract books from the Union Conference on TB and Lung Disease were screened for the term 'stigma'.

Three reviewers (NS, LR and $\mathrm{MN}$ ) screened (in parallel) potentially eligible studies for original research in which the title, abstract or key words suggested the evaluation of reduction of TB stigma. In the second eligibility screening, the full texts of selected studies were reviewed by two reviewers (NS and $\mathrm{CM}$ ) using standardised eligibility criteria. Discrepancies were solved by consensus. Reasons for excluding potentially eligible studies were listed, and the full papers of the selected articles were read by two researchers (NS and CM) to extract information (for coding scheme, see Appendix Tables A.1A.3) (Figure).*

\section{Assessment of study quality}

Three authors (NS, CM and EW) independently assessed the quality of the selected studies using the Downs and Black scale, ${ }^{12}$ which can be used to assess the evidence of both randomised controlled trials and quasi-experimental studies, even if the studies lack a control group. ${ }^{13}$ For qualitative individual studies, we applied the guidelines created by Spencer et al., as recommended by the Cochrane group, 8,14 and each assessment question was awarded $0-3$ points.

\section{RESULTS}

Seven articles published between 1999 and 2015 in peer-reviewed journals were retained in the review. Three originated from Central and South America, ${ }^{15-17}$ two from Africa ${ }^{4,18}$ and two from Asia. ${ }^{19,20}$ Most interventions had stigma reduction as one of several main aims: three studies also aimed to increase knowledge about $\mathrm{TB},{ }^{18-20}$ two also aimed to improve TB treatment adherence ${ }^{4,16}$ and one also aimed to improve knowledge about leprosy and TB (Table 1). ${ }^{19}$

\section{Methodology and stigma types}

Of the seven studies, five targeted anticipated stigma,

* The appendix is available in the online version of this article, at
$\mathrm{http}: / / \mathrm{www}$.ingentaconnect.com/content/iuatld/ijtld/2017/ 00000021/a00111s1/art00013 
two internalised stigma, but no studies focused on enacted stigma. Chalco et al. mentioned the ostracising of TB patients by household members, but did not provide examples of how it might have been affected by the intervention ${ }^{16}$ (see Appendix Table A.4). Of the studies targeting anticipated stigma, two were quasi-experimental before-and-after studies without a control group, ${ }^{18,20}$ one had a retrospective casecontrol design, with cases and controls selected from different regions, ${ }^{19}$ and one was a qualitative study using focus groups and in-depth interviews with participants of 'TB clubs', where people with TB meet, share experiences and take responsibility for each other's treatment process. ${ }^{4}$ Of the two studies aimed at reducing internalised stigma, one was a qualitative study using participant observation and focus groups, ${ }^{15}$ and the other used a quantitative quasi-experimental design. ${ }^{17}$ One ethnographic study was based on both anticipated and internalised stigma using structured observations and focus groups. ${ }^{16}$

\section{Interventions to reduce stigma}

Overall, two of the seven interventions aimed to reduce TB stigma focused on the general community, ${ }^{18,19}$ four focused on TB patients, including two on multidrug-resistant TB (MDR-TB) patients ${ }^{4,15-17}$ and one on HCWs, including community workers. ${ }^{20}$ The effect of the intervention was measured in TB patients ( $n=268,7 \mathrm{~TB}$ clubs and 42 focus-group sessions, including one study that evaluated MDR-TB patients), ${ }^{4,15,17}$ in HCWs $(n=1266)^{16,20}$ and in the general community $(n=352) .18,19$

To clarify the nature of how the interventions might work and thus improve and facilitate the accuracy of future replication, the review identified behaviour-change methods, i.e., 'the observable and replicable component designed to change behaviour inherent to the interventions'. ${ }^{21}$ Several types of interventions were evaluated in the studies included (see Table 1 for a more detailed description of interventions). Of the five interventions aimed at reducing anticipated stigma, ${ }^{4,16,18-20}$ most used attitude-changing or knowledge-shaping components. These components educated the general population, family members and/or $\mathrm{TB}$ patients about TB while also projecting positive images of TB patients. ${ }^{16,18-20}$

Balogun et al. used an interactive approach to knowledge shaping: community workers were trained to spread information about $\mathrm{TB}$ in the community. ${ }^{18}$ Croft and Croft used mass media dissemination tools such as loudspeakers, large film screenings and flipcharts. ${ }^{19} \mathrm{Wu}$ et al. evaluated an attitude- and knowledge-shaping training course for HCWs. Chalco et al. also evaluated attitude-changing interactions of nurses with the general community and families of people with MDR-TB, to empower the latter to be more self-sufficient. ${ }^{16}$ Demissie et al. evaluated an intervention using TB clubs (see above). ${ }^{4}$

Two of the studies aimed at reducing internalised stigma identified community nurses as important agents. ${ }^{15,16}$ Acha et al., for example, studied the impact of nurse-led psychosocial patient support groups, celebrations, excursions and family workshops for MDR-TB patients. ${ }^{15}$ Macq et al. evaluated an intervention with TB clubs and patient-centred home visits by HCWs. ${ }^{17}$

\section{Measurements and results}

All but one study concluded that their intervention had reduced stigma. ${ }^{18}$ Because different outcome measurements were used, it was not possible to compare the strengths of the effects between studies or to summarise the impact of stigma-reduction interventions. To measure the effect of the intervention on stigmatising attitudes towards people with TB, several outcome measures were used (Table 1).

Wu et al. used a validated (Cronbach's $\alpha 0.7$ ) eightitem scale adapted from the Attribution Questionnaire (AQS8) for mental illness. ${ }^{20}$ The intervention slightly reduced anticipated stigma in public HCWs, but not in facility-based DOTS workers. Croft and Croft measured attitudes toward TB in the general population using four questions. They found that the information campaign effectively improved attitudes towards people with TB on all the questions that they used to measure stigma. ${ }^{19}$ Using qualitative methods, Demissie et al. established that participation in TB clubs led to increased understanding of $\mathrm{TB}$, a reduction in social and financial isolation, and increased adherence to treatment. ${ }^{4}$ Chalco et al. reported qualitative evidence for improved attitudes and reduced fear towards MDR-TB patients among family members and the general community after home visits by community nurses. ${ }^{16}$ Using a validated 10-item scale (Cronbach's $\alpha$ 0.7), ${ }^{17}$ Macq et al. observed improvements in internalised stigma in the intervention group after 2 months. Acha et al. and Chalco et al. identified that support groups and community nurses led to the reduction of internalised stigma and improved treatment adherence in MDRTB patients, respectively. ${ }^{15,16}$ In contrast, based on results of two questions ('stays away from people with TB' and 'fears people with TB'), Balogun et al. reported that stigmatising attitudes among the general community increased after community volunteers disseminated TB knowledge (Table 1). ${ }^{18}$

\section{Quality assessment}

We found a general lack of quality in the TB stigmaintervention studies. As there are no established quality criteria, we calculated the percentages of the total possible score to give an indication of quality (Table 2). Scores ranged from 7 to 11 on the Downs and Black Scale (out of a maximum of 27). For 
Table 1 Study and intervention characteristics, stigma types and results from seven studies

\begin{tabular}{|c|c|c|c|c|}
\hline $\begin{array}{l}\text { First author, } \\
\text { year, reference }\end{array}$ & Country & $\begin{array}{c}\text { Study } \\
\text { population }\end{array}$ & Outcome & Sample \\
\hline Acha, $2007^{15}$ & Peru & MDR-TB patients & $\begin{array}{l}\text { Reduction in internalised } \\
\text { stigma in MDR-TB } \\
\text { patients }\end{array}$ & $\begin{array}{l}42 \text { support group } \\
\text { sessions }\end{array}$ \\
\hline Balogun, $2015^{18}$ & Nigeria & General community & $\begin{array}{l}\text { Reduction in anticipated } \\
\text { stigma in the general } \\
\text { community }\end{array}$ & 252 \\
\hline Chalco, $2006^{16}$ & Peru & Nurses & $\begin{array}{l}\text { Reduction in internalised } \\
\text { stigma in MDR-TB } \\
\text { patients }\end{array}$ & 7 \\
\hline Croft, $1999^{19}$ & Bangladesh & General community & $\begin{array}{l}\text { Reduction in anticipated } \\
\text { stigma in the general } \\
\text { community }\end{array}$ & 100 \\
\hline Demissie, $2003^{4}$ & Ethiopia & TB patients & $\begin{array}{l}\text { Reduction in anticipated } \\
\text { stigma in the TB patients } \\
\text { and the general } \\
\text { community }\end{array}$ & 11 TB clubs \\
\hline Macq, $2008^{17}$ & Nicaragua & TB patients & $\begin{array}{l}\text { Reduction in internalised } \\
\text { and anticipated stigma in } \\
\text { TB patients }\end{array}$ & 268 \\
\hline Wu, $2009^{20}$ & Taiwan & HCWs & $\begin{array}{l}\text { Reduction in anticipated } \\
\text { stigma in HCWs }\end{array}$ & 1259 \\
\hline
\end{tabular}

$* P<0.05$.

${ }^{+} P<0.01$.

$\mathrm{MDR}-\mathrm{TB}=$ multidrug-resistant TB; NA = not applicable; TB = tuberculosis; $\mathrm{HCW}=$ health care worker.

qualitative studies, the score ranged from 26 to 35 based on the framework of Spencer et al. (out of a maximum of 53) (see Appendix Tables A.5-A.7, Table 2).

\section{DISCUSSION}

The results of this first systematic review of TB stigma interventions showed a lack of reliable information on evidence-based interventions for anticipated and internalised stigma, and no evidence-based intervention for enacted stigma. Of the seven studies included, most $(5 / 7)$ evaluated an intervention to reduce anticipated stigma, and almost all (6/7) showed a reduction in TB stigma. However, one study reported that the training of community volunteers resulted in increased stigma towards people with $\mathrm{TB}$, but this was based on responses to two questions: 'stays away from people with TB' and 'fears people with TB'. The authors suggest that the observed negative effects may have been due to poorly trained community volunteers who might have perpetuated stigmatising attitudes or due to the fear in response to learning that TB is transmitted by air. ${ }^{18}$ Stigma interventions therefore need carefully crafted messaging and design as well as trained messengers. As one of the seven described interventions had a negative outcome of increased stigma, it is important to avoid publication bias and ensure that all evaluations-even those that are unsuccessful interventions-are published.22

While the strength of this review is its comprehensiveness, several limitations must be noted. First, the shortage of interventions evaluated using a scientific approach and the use of different outcome measures made the comparison and summary of effect sizes impossible. For future evaluations, attention should be paid well in advance to how stigma is measured, preferably using validated and 
Table 1 (continued)

\begin{tabular}{|c|c|c|c|}
\hline Intervention type/s & Study design & $\begin{array}{l}\text { Measurement } \\
\text { unit }\end{array}$ & Results \\
\hline $\begin{array}{l}\text { Psychosocial support groups: intervention comprised four } \\
\text { components-support groups, recreational excursions, } \\
\text { symbolic celebrations and family workshops }\end{array}$ & Qualitative & NA & $\begin{array}{l}\text { The support groups were effective } \\
\text { against the negative social } \\
\text { impact faced by MDR-TB patients }\end{array}$ \\
\hline $\begin{array}{l}\text { Awareness raising by community volunteers. Community } \\
\text { volunteers organised health talks in markets, churches and } \\
\text { mosques targeting households and different occupational } \\
\text { groups, and one-on-one discussions with other } \\
\text { community members. They also delivered educational } \\
\text { pamphlets door-to-door and posters on every street to aid } \\
\text { the health talks, and held a rally to create awareness }\end{array}$ & $\begin{array}{l}\text { Quasi- } \\
\text { experimental }\end{array}$ & 2 items & $\begin{array}{l}\text { Stays away from people with TB: } \\
\text { pre-intervention } 13.5 \% \text {, post- } \\
\text { intervention } 34.9 \% \text { * } \\
\text { Fears people with TB: pre- } \\
\text { intervention } 0.8 \% \text {, post- } \\
\text { intervention } 6.7 \% \text { * }\end{array}$ \\
\hline $\begin{array}{l}\text { Community nursing: nurses visited the homes of patients to } \\
\text { better understand the patient, the patient's family and the } \\
\text { patient's environment. Information was used to adjust } \\
\text { treatment to patient needs, including factors that can } \\
\text { facilitate or hinder treatment. Communication with } \\
\text { patient's family to reduce stigma }\end{array}$ & Qualitative & NA & $\begin{array}{l}\text { Support from nurses reduced the } \\
\text { internal stigma of MDR-TB } \\
\text { patients }\end{array}$ \\
\hline $\begin{array}{l}\text { Health education programme: included a day/night mass } \\
\text { information programme run from a jeep using flipcharts, a } \\
\text { bullhorn loudspeaker and two locally developed slide } \\
\text { series showing simple stories about TB sufferers who } \\
\text { receive successful treatment. The slide series was shown } \\
\text { five times in evening sessions over } 2 \text { years, with an } \\
\text { audience of several hundred each time. In addition, in } \\
1995 \text { all schools were visited and given information }\end{array}$ & Case control & 4 items & $\begin{array}{l}\text { Stigma was significantly lower in } \\
\text { the intervention group for all } \\
\text { four items }\end{array}$ \\
\hline $\begin{array}{l}\text { TB clubs: each club had regular weekly meetings conducted } \\
\text { in places such as churches, mosques, market places or } \\
\text { other venues for social events to support each other in } \\
\text { adhering to treatment and to share information about the } \\
\text { course of the disease and possible drug side effects. } \\
\text { Patients failing to make satisfactory progress or suffering } \\
\text { from side effects were reported to the health centre }\end{array}$ & Qualitative & NA & $\begin{array}{l}\text { The intervention with TB clubs had } \\
\text { improved the societal attitudes } \\
\text { toward TB patients and increased } \\
\text { confidence and reduced fear of } \\
\text { disclosure in TB patients }\end{array}$ \\
\hline $\begin{array}{l}\text { TB clubs, home visits: group of TB patients benefitted from a } \\
\text { patient-centred intervention package, including at least TB } \\
\text { clubs and home visits, and a control group in rural } \\
\text { Nicaragua. Increased power-sharing between health } \\
\text { personnel and TB patients (i.e., giving more power to the } \\
\text { patient in the health care provider-patient interaction) }\end{array}$ & $\begin{array}{l}\text { Quasi- } \\
\text { experimental }\end{array}$ & $\begin{array}{l}\text { Validated } 10 \text { item } \\
\text { scale: range } 10-50 \\
\text { (higher is more } \\
\text { stigma) }\end{array}$ & $\begin{array}{l}\text { After } 2 \text { months: control group } \\
33.1 \text {, intervention group } 27.4^{\dagger} \\
\text { Difference between } 2 \text { months and } \\
15 \text { days: control group } 1.5, \\
\text { intervention group } 4.3^{*}\end{array}$ \\
\hline $\begin{array}{l}\text { Educational workshops: health care workers attended a } \\
\text { training course which included knowledge about } \\
\text { destigmatisation and human rights of TB patients }\end{array}$ & $\begin{array}{l}\text { Quasi- } \\
\text { experimental }\end{array}$ & $\begin{array}{l}\text { Validated } 8 \text {-item } \\
\text { scale: range } 8-40 \\
\text { (higher is more } \\
\text { stigma) }\end{array}$ & $\begin{array}{l}\text { t-tests: public HCWs pre- } \\
\text { intervention } 36.83 \text {, post- } \\
\text { intervention 35.69* } \\
\text { DOTS workers pre-intervention } \\
\text { 36.91, post-intervention } 36.15\end{array}$ \\
\hline
\end{tabular}

standardised instruments to enable meta-analysis (for example, those used by Courtwright and Turner, Macq et al., Wouters et al. and Açikel and Pakyüz ${ }^{23-}$ $\left.{ }^{26}\right)$. Second, as for all systematic reviews, the quality of this review was determined in part by the quality of the original studies. Quality assessments revealed major flaws in the methodology and reporting of most studies. Future research should pay greater attention to using a sound evaluation design to

Table 2 Quality assessment scores using different assessment tools

\begin{tabular}{llc}
\hline $\begin{array}{l}\text { Author, year, } \\
\text { reference }\end{array}$ & Assessment tool & $\begin{array}{c}\text { Quality } \\
\text { assessment score }\end{array}$ \\
\hline Balogun, 201518 & Downs and Black & $11 / 27$ \\
Croft, 199919 & Downs and Black & $7 / 27$ \\
Macq, 2008 & Downs and Black & $11 / 27$ \\
Wu, 200920 & Downs and Black & $9 / 27$ \\
Acha, 200715 & Spencer et al. & $35 / 54$ \\
Chalco, 2006 & Spencer et al. & $26 / 54$ \\
Demissie, 2003 & Spencer et al. & $34 / 54$ \\
\hline
\end{tabular}

ensure reliable evidence. Third, most studies assessed at least two intervention components and measured multiple outcomes. ${ }^{4,15,16,18-20}$ This approach made attribution of the effect of the different components on the outcomes difficult. This was particularly the case if different outcomes were interconnected, such as stigma and treatment adherence. Researchers should define the order of the outcomes and the change mechanism of the intervention. Evidence of interventions to reduce the stigma attached to infection by the human immunodeficiency virus has also stressed the importance of targeting not only one but several levels where the mechanisms of stigma work in combined interventions. ${ }^{27}$

\section{CONCLUSION}

Despite the importance of stigma reduction to achieve the goal of TB elimination, few stigma-reduction interventions have been rigorously evaluated, and 
none of the interventions showing positive effects have been replicated. Based on the existing body of evidence and our quality assessment, support groups such as TB clubs, combined with a conscious focus on improving attitudes in the general community, showed promising results in reducing both internalised and anticipated stigma. ${ }^{4,15,17}$ There may also be synergies in simultaneously engaging a range of populations, such as TB patients, their families, and HCWs, in multivalent stigma interventions. ${ }^{15,16,28}$

\section{Acknowledgements}

The Global Health Bureau, Office of Health, Infectious Disease and Nutrition (HIDN), US Agency for International Development (USAID, Washington DC, USA), financially supports this study through Challenge TB under the terms of Agreement No. AIDOAA-A-14-00029. The authors' views expressed in this publication do not necessarily reflect the views of USAID or the US Government.

Comments from the TB Stigma Working Group are gratefully acknowledged.

Conflicts of interest: none declared.

\section{References}

1 World Health Organization. The top 10 causes of death. Geneva, Switzerland: WHO, 2017. http://www.who.int/ mediacentre/factsheets/fs310/en/index2.html. Accessed July 2017.

2 Zaman K. Tuberculosis: a global health problem. J Health Popul Nutr 2010; 28: 111-113.

3 Mason P H, Roy A, Spillane J, Singh P. Social, historical and cultural dimensions of tuberculosis. J Biosoc Sci 2016; 48: 206232.

4 Demissie M, Getahun H, Lindtjorn B. Community tuberculosis care through 'TB clubs' in rural North Ethiopia. Soc Sci Med 2003; 56: 2009-2018.

5 Juniarti N, Evans D. A qualitative review: the stigma of tuberculosis. J Clin Nurs 2011; 20: 1961-1970.

6 Courtwright A, Turner A N. Tuberculosis and stigmatization: pathways and interventions. Public Health Rep 2010; 125 (Suppl 4): 34-42.

7 Earnshaw V A, Chaudoir S R. From conceptualizing to measuring HIV stigma: a review of HIV stigma mechanism measures. AIDS Behav 2009; 13: 1160-1177.

8 Higgins J P T, Green S. Cochrane handbook for systematic reviews of interventions: the Cochrane Collaboration. London, UK: Cochrane, 2011. www.cochrane-handbook.org. Accessed November 2015.

9 Earnshaw V A, Smith L R, Chaudoir S R, Amico K R, Copenhaver M M. HIV stigma mechanisms and well-being among PLWH: a test of the HIV stigma framework. AIDS Behav 2013; 17: 1785-1795.

10 Greenhalgh T, Peacock R. Effectiveness and efficiency of search methods in systematic reviews of complex evidence: audit of primary sources. BMJ 2005; 331: 1064-1065.

11 Rockers P C, Feigl A B, Røttingen J-A, et al. Study-design selection criteria in systematic reviews of effectiveness of health systems interventions and reforms: a meta-review. Health Policy 2012; 104: 206-214.

12 Downs S H, Black N. The feasibility of creating a checklist for the assessment of the methodological quality both of randomised and non-randomised studies of health care interventions. J Epidemiol Community Health 1998; 52: 377384.

13 Fitzpatrick-Lewis D, Ciliska D, Thomas H. Methods for the synthesis of studies without control groups. Hamilton, ON, USA: National Collaborating Centre for Methods and Tools, 2009.

14 Spencer L, Ritchie J, Lewis J, Dillon L. Quality in qualitive evaluation: a framework for assessing research evidence. London, UK: UK Government Chief Social Researcher's Office, 2003.

15 Acha J, Sweetland A, Guerra D, Chalco K, Castillo H, Palacios E. Psychosocial support groups for patients with multidrugresistant tuberculosis: five years of experience. Glob Public Health 2007; 2: 404-417.

16 Chalco K, Wu D, Mestanza L, et al. Nurses as providers of emotional support to patients with MDR-TB. Int Nurs Rev 2006; 53: 253-260.

17 Macq J, Solis A, Martinez G, Martiny P. Tackling tuberculosis patients' internalized social stigma through patient centred care: an intervention study in rural Nicaragua. BMC Public Health 2008; 8: 154.

18 Balogun M, Sekoni A, Meloni S, et al. Trained community volunteers improve tuberculosis knowledge and attitudes among adults in a periurban community in southwest Nigeria. Am J Trop Med Hyg 2015; 92: 625-632.

19 Croft R P, Croft R A. Knowledge, attitude and practice regarding leprosy and tuberculosis in Bangladesh. Lepr Rev 1999; 70: 34-42.

20 Wu P S, Chou P, Chang N T, Sun W J, Kuo H S. Assessment of changes in knowledge and stigmatization following tuberculosis training workshops in Taiwan. J Formos Med Assoc 2009; 108: 377-385.

21 Michie S, Wood C, Johnston M, Abraham C, Francis J. Behaviour change techniques: the development and evaluation of a taxonomic method for reporting and describing behaviour change interventions (a suite of five studies involving consensus methods, randomised controlled trials and analysis of qualitative data). Health Technol Assess 2015; 19: 1-188.

22 Torgerson C J. Publication bias: the Achilles' heel of systematic reviews? Br J Educ Stud 2006; 54: 89-102.

23 Courtwright A, Turner A N. Tuberculosis and stigmatization: pathways and interventions. Public Health Reports 2010; 125 (Suppl 4): 34-42.

24 Macq J, Solis A, Martinez G. Assessing the stigma of tuberculosis. Psychol Health Med 2006; 11: 346-352.

25 Wouters E, Rau A, Engelbrecht M, et al. The development and piloting of parallel scales measuring external and internal HIV and tuberculosis stigma among healthcare workers in the Free State Province, South Africa. Clin Infect Dis 2016; 62 (Suppl 3): S244-S254.

26 Açikel G Y, Pakyüz S Ç. Akciğer tüberkülozlu hastalarda damgalamanin değerlendirilmesi. Florence Nightingale Hemşirelik Dergisi 2015; 23: 136-145.

27 Stangl A L, Lloyd J K, Brady L M, Holland C E, Baral S. A systematic review of interventions to reduce HIV-related stigma and discrimination from 2002 to 2013: how far have we come? J Int AIDS Soc 2013; 16 (Suppl 2): 18734.

28 Heunis J C, Wouters E, Norton W, et al. Patient- and deliverylevel factors related to acceptance of HIV counseling and testing services among tuberculosis patients in South Africa: a qualitative study with community health workers and program managers. Implement Sci 2011; 6: 27. 


\section{APPENDIX}

Inclusion criteria

Table A.1 First eligibility screen

\begin{tabular}{lll}
\hline Variable & \multicolumn{1}{c}{ Explanation } & Answer categories \\
\hline $\begin{array}{l}\text { study_id } \\
\text { reviewer }\end{array}$ & $\begin{array}{l}\text { Individual study ID } \\
\text { Review author name }\end{array}$ & \\
title & Title & Article, report, website \\
type & Type of literature & Electronic database, citation, manual search, website \\
source & How was the study found? & English, Spanish, Portuguese, German, Dutch, French, other \\
language & Is the language English, Spanish, Portuguese, German, & \\
& $\quad$ Dutch or French? & Yes, no \\
tb_stigma & Does the study address TB stigma? & Yes, no \\
intervention & Does the study contain an intervention aimed at reducing TB & \\
stigma? & Does the study fit all the inclusion criteria? & Yes, no, unclear \\
included & Review authors' comments &
\end{tabular}

$\mathrm{TB}=$ tuberculosis.

Table A.2 Second eligiblity screen

\begin{tabular}{|c|c|c|}
\hline Variable & Explanation & Answer categories \\
\hline study_id & $\begin{array}{l}\text { Individual study ID (can start with different number for each } \\
\text { author extracting data) }\end{array}$ & \\
\hline reviewer & Review author name & \\
\hline title & Title & \\
\hline authors & Author/s & \\
\hline participants & $\begin{array}{l}\text { Is the study population the general community, TB patients } \\
\text { or care givers? }\end{array}$ & General community, TB patient, care giver, other \\
\hline method & $\begin{array}{l}\text { Is the method for the intervention assessment experimental, } \\
\text { quasi-experimental, qualitative, mixed methods or a } \\
\text { review study? }\end{array}$ & $\begin{array}{l}\text { RCT/CRCT (control for intragroup variance), quasi- } \\
\text { experimental (method for controlling bias/matching), } \\
\text { mixed methods, qualitative, review study, other }\end{array}$ \\
\hline included & Does the study fit all the inclusion criteria? & Yes, no, unclear \\
\hline exclusion_reason & What was the reason for exclusion? & \\
\hline comments & Review authors' comments & \\
\hline
\end{tabular}

$\mathrm{TB}=$ tuberculosis; $\mathrm{RCT}=$ randomised controlled trial; $\mathrm{CRCT}=$ cluster $\mathrm{RCT}$. 
Table A.3 Data abstraction

\begin{tabular}{|c|c|c|}
\hline Variable & Explanation & Answer categories \\
\hline study_id & Individual study ID & \\
\hline report_id & Report ID & \\
\hline reviewer & Review author name & \\
\hline & Title & \\
\hline authors & Author/s & \\
\hline year & Year of publication & \\
\hline citcon & Citation and contact details & \\
\hline type & Type of literature & Article, report, website \\
\hline source & & Electronic database, citation, manual search, website \\
\hline language & $\begin{array}{l}\text { Is the language English, Spanish, Portuguese, German, } \\
\text { Dutch or French? }\end{array}$ & English, Spanish, Portuguese, German, Dutch, French \\
\hline \multicolumn{3}{|l|}{ Intervention } \\
\hline Intervention purpose & $\begin{array}{l}\text { Is the study outcome to improve stigma-related attitudes } \\
\text { among the general community, improve self-concept } \\
\text { for people with TB, and improve the behaviours of } \\
\text { care givers? }\end{array}$ & General attitudes, self-concept, improve care givers \\
\hline participants1 & $\begin{array}{l}\text { Is the study population the general community, TB } \\
\text { patients or care givers? }\end{array}$ & General community, TB patient, care giver \\
\hline stigma_participant1 & $\begin{array}{l}\text { Is this population assumed to be stigmatising or being } \\
\text { stigmatised? }\end{array}$ & Stigmatising, stigmatised \\
\hline stigma_type1 & What type of stigma is the target for this population? & Anticipated, internalised, enacted \\
\hline age1 & What age were the participants? & \\
\hline number 1 & Total number of this group of participants & \\
\hline participants2 & Does the study have a second population type? & General community, TB patient, care giver \\
\hline stigma_participant2 & $\begin{array}{l}\text { Is this population assumed to be stigmatising or being } \\
\text { stigmatised? }\end{array}$ & Stigmatising, stigmatised \\
\hline stigma_type2 & What type of stigma is the target for this population? & Anticipated, internalised, enacted \\
\hline age2 & What age were the participants? & \\
\hline number2 & Total number of this group of participants & \\
\hline participants3 & Does the study have a third population type? & General community, TB patient, care giver \\
\hline stigma_participant3 & $\begin{array}{l}\text { Is this population assumed to be stigmatising or being } \\
\text { stigmatised? }\end{array}$ & Stigmatising, stigmatised \\
\hline stigma_type3 & What type of stigma is the target for this population? & Anticipated, internalised, enacted \\
\hline age3 & What age were the participants? & \\
\hline number3 & Total number of this group of participants & \\
\hline intervention_type & What type of intervention? & $\begin{array}{l}\text { Information campaign, skill building, counselling, } \\
\text { contact/interaction }\end{array}$ \\
\hline specific_intervention & Describe the intervention & \\
\hline HIV & Was the study targeting both HIV and TB stigma? & HIV/TB, only TB \\
\hline \multicolumn{3}{|l|}{ Methods } \\
\hline study_design & $\begin{array}{l}\text { RCT/CRCT (with query control for intragroup variance)/ } \\
\text { quasi-experimental (method for controlling bias/ } \\
\text { matching), mixed methods, qualitative, review study }\end{array}$ & $\begin{array}{l}\text { Experimental (with query control for intragroup } \\
\text { variance), quasi-experimental (method for controlling } \\
\text { bias/matching), mixed methods, qualitative, review } \\
\text { study, other }\end{array}$ \\
\hline mixed_type & $\begin{array}{l}\text { In the mixed-methods study, was the outcome of interest } \\
\text { in the quantitative or qualitative module (or both)? }\end{array}$ & Quantitative, qualitative, both \\
\hline quant_type & What type of quantitative study? & RCT, CRTC, longitudinal, cross-sectional \\
\hline qual_type & What type of qualitative study? & $\begin{array}{l}\text { Phenomenology, ground theory, ethnography, action } \\
\text { research, descriptive study }\end{array}$ \\
\hline $\begin{array}{l}\text { review_type } \\
\text { duration }\end{array}$ & $\begin{array}{l}\text { What type of review study? } \\
\text { Total study duration (months) }\end{array}$ & Descriptive, meta study \\
\hline \multicolumn{3}{|l|}{ Outcomes } \\
\hline anticipated_outcome & Outcome definition anticipated stigma & \\
\hline internal_outcome & Outcome definition internalised stigma & \\
\hline enacted_outcome & Outcome definition enacted stigma & \\
\hline unit_anticipated & Unit of measurement, anticipated stigma & \\
\hline unit_ internal & Unit of measurement, internalised stigma & \\
\hline unit_enacted & Unit of measurement, enacted stigma & \\
\hline scale_range & $\begin{array}{l}\text { For scales: upper and lower limits, and whether high or } \\
\text { low score is good }\end{array}$ & \\
\hline scale_valid & For scales: if validated & Yes, no \\
\hline \multicolumn{3}{|l|}{ Result } \\
\hline \multicolumn{3}{|l|}{ Anticipated stigma (a) } \\
\hline n_group_a & $\begin{array}{l}\text { Number of participants allocated to each intervention } \\
\text { group }\end{array}$ & \\
\hline n_a & Sample size & \\
\hline missing_a & Missing participants & \\
\hline result_summary_a & $\begin{array}{l}\text { Summary data for each intervention group (e.g., } 2 \times 2 \\
\text { table for dichotomous data; means and standard } \\
\text { deviations for continuous data, summarising matrix or } \\
\text { other from qualitative data) }\end{array}$ & \\
\hline
\end{tabular}


Table A.3 (continued)

\begin{tabular}{|c|c|c|}
\hline Variable & Explanation & Answer categories \\
\hline effect_a & $\begin{array}{l}\text { Estimate of the effect with confidence interval; } P \text { value. } \\
\text { Increase/decrease in stigma for qualitative reviews }\end{array}$ & \\
\hline \multicolumn{3}{|c|}{ Internalised stigma (i) } \\
\hline n_group_i & $\begin{array}{l}\text { Number of participants allocated to each intervention } \\
\text { group }\end{array}$ & \\
\hline n_i & Sample size & \\
\hline missing_i & Missing participants & \\
\hline result_summary_i & $\begin{array}{l}\text { Summary data for each intervention group (e.g., } 2 \times 2 \\
\text { table for dichotomous data; means and standard } \\
\text { deviations for continuous data, summarising matrix or } \\
\text { other from qualitative data) }\end{array}$ & \\
\hline effect_i & $\begin{array}{l}\text { Estimate of the effect with confidence interval; } P \text { value. } \\
\text { Increase/decrease in stigma for qualitative reviews }\end{array}$ & \\
\hline \multicolumn{3}{|l|}{ Enacted stigma (e) } \\
\hline n_group_e & $\begin{array}{l}\text { Number of participants allocated to each intervention } \\
\text { group }\end{array}$ & \\
\hline n_e & Sample size & \\
\hline missing_e & Missing participants & \\
\hline result_summary_e & $\begin{array}{l}\text { Summary data for each intervention group (e.g., } 2 \times 2 \\
\text { table for dichotomous data; means and standard } \\
\text { deviations for continuous data, summarizing matrix or } \\
\text { other from qualitative data) }\end{array}$ & \\
\hline effect_i & $\begin{array}{l}\text { Estimate of the effect with confidence interval; } P \text { value. } \\
\text { Increase/decrease in stigma for qualitative reviews }\end{array}$ & \\
\hline \multicolumn{3}{|l|}{ Miscellaneous } \\
\hline funding_source & Funding source & \\
\hline references & References to other relevant studies & \\
\hline correspondence & Correspondence required & \\
\hline comments_author & Comments by the review authors & \\
\hline
\end{tabular}

$\mathrm{TB}=$ tuberculosis; HIV = human immunodeficiency virus; $\mathrm{RCT}=$ randomised controlled trial; $\mathrm{CRCT}=$ cluster RCT.

Table A.4 Excluded studies describing a TB stigma-reducing intervention but no intervention outcome effect, or not fulfilling the methodological criteria

\begin{tabular}{|c|c|c|c|}
\hline $\begin{array}{l}\text { First author, year, } \\
\text { reference }\end{array}$ & Country & $\begin{array}{l}\text { Population in which to reduce } \\
\text { stigma and type of stigma }\end{array}$ & Intervention \\
\hline Chalco, $2006^{1}$ & Peru & $\begin{array}{l}\text { Enacted stigma in families of TB } \\
\text { patients }\end{array}$ & $\begin{array}{l}\text { Community nurses talked to family members about TB to } \\
\text { create understanding for the ill family member and } \\
\text { end ostracising behaviour }\end{array}$ \\
\hline Dick, $2004^{2}$ & South Africa & $\begin{array}{l}\text { Enacted stigma in HCWs towards } \\
\text { TB patients }\end{array}$ & $\begin{array}{l}\text { Education programme focusing on patient-centred care: } \\
\text { visualised stories describing the hardship, stigma and } \\
\text { difficulties of having TB. This exercise provoked lively } \\
\text { discussion on the psychosocial aspects of case } \\
\text { management in the clinical context }\end{array}$ \\
\hline Karels, $2014^{3}$ & The Netherlands & $\begin{array}{l}\text { Anticipated stigma in a Somali } \\
\text { population in the Netherlands }\end{array}$ & $\begin{array}{l}\text { A TB awareness-raising programme involving the } \\
\text { Somalian community. After the programme, it was } \\
\text { easier to talk openly about TB within the population }\end{array}$ \\
\hline Liefhooge, $1999^{4}$ & Pakistan & Internalised stigma in TB patients & $\begin{array}{l}\text { Informational and motivational counselling to improve } \\
\text { TB patient's self-efficacy }\end{array}$ \\
\hline Machmud, $2015^{5}$ & Indonesia & $\begin{array}{l}\text { Anticipated stigma in elementary } \\
\text { school children }\end{array}$ & $\begin{array}{l}\text { Knowledge building: colouring book competition to } \\
\text { learn about TB, incorporating a committee of } \\
\text { government officials }\end{array}$ \\
\hline Mohammed, $2015^{6}$ & Pakistan & $\begin{array}{l}\text { Internalised stigma in TB patients, } \\
\text { anticipated stigma in the general } \\
\text { community }\end{array}$ & $\begin{array}{l}\text { Patient empowerment and awareness raising using } \\
\text { Photovoice, a participatory qualitative action research } \\
\text { methodology to help TB patients document their story } \\
\text { through photography. Resulted in an exhibition for the } \\
\text { general public }\end{array}$ \\
\hline Moya, $2015^{7}$ & Mexico & $\begin{array}{l}\text { Internalised stigma in people with } \\
\text { TB }\end{array}$ & $\begin{array}{l}\text { Nuestra Casa, a portable house was built where stories of } \\
\text { TB patients were told and displayed for the general } \\
\text { public, said to have an empowering effect on TB } \\
\text { patients }\end{array}$ \\
\hline Unmask Stigma, $2015^{8}$ & South Africa & $\begin{array}{l}\text { Internalised and anticipated stigma } \\
\text { among HCWs }\end{array}$ & $\begin{array}{l}\text { An international awareness and education initiative } \\
\text { aimed to unmask and expose the true character or } \\
\text { hidden truth about a set of negative (and often unfair) } \\
\text { beliefs about a particular circumstance, quality or } \\
\text { person surrounding TB }\end{array}$ \\
\hline
\end{tabular}


Table A.5 Downs and Black checklist for non-randomised studies

\begin{tabular}{|c|c|c|c|c|c|}
\hline \multirow{2}{*}{\multicolumn{2}{|c|}{ Answers: yes, no, unable to determine }} & \multicolumn{4}{|c|}{ Author, year, reference } \\
\hline & & $\begin{array}{c}\text { Balogun, } \\
2015^{18}\end{array}$ & $\begin{array}{l}\text { Wu, } \\
2009^{20}\end{array}$ & $\begin{array}{l}\text { Macq, } \\
2008^{17}\end{array}$ & $\begin{array}{l}\text { Croft, } \\
1999^{19}\end{array}$ \\
\hline 1 & $\begin{array}{l}\text { Is the hypothesis/aim/objective of the study clearly described? Must be } \\
\text { explicit Yes/No }\end{array}$ & Yes & Yes & Yes & Yes \\
\hline 2 & $\begin{array}{l}\text { Are the main outcomes to be measured clearly described in the } \\
\text { Introduction or Methods section? If the main outcomes are first } \\
\text { mentioned in the Results section, the question should be answered } \\
\text { 'no'. ALL primary outcomes should be described for 'yes' }\end{array}$ & Yes & Yes & Yes & Yes \\
\hline 3 & $\begin{array}{l}\text { Are the characteristics of the participants included in the study clearly } \\
\text { described? In cohort studies and trials, inclusion and/or exclusion } \\
\text { criteria should be given. In case-control studies, a case-definition and } \\
\text { the source for controls should be given. Single case studies must } \\
\text { state the source of patients }\end{array}$ & Yes & Yes & Yes & Yes \\
\hline 4 & $\begin{array}{l}\text { Are the interventions of interest clearly described? Treatments and } \\
\text { placebo (where relevant) that are to be compared should be clearly } \\
\text { described }\end{array}$ & Yes & Yes & Yes & Yes \\
\hline 5 & $\begin{array}{l}\text { Are the distributions of principal confounders in each group of subjects } \\
\text { to be compared clearly described? A list of principal confounders is } \\
\text { provided. Yes = age, severity }\end{array}$ & Yes & Yes & Yes & Yes \\
\hline 6 & $\begin{array}{l}\text { Are the main findings of the study clearly described? Simple outcome } \\
\text { data (including denominators and numerators) should be reported } \\
\text { for all major findings so that the reader can check the major analyses } \\
\text { and conclusions }\end{array}$ & Yes & No & Yes & Yes \\
\hline 7 & $\begin{array}{l}\text { Does the study provide estimates of the random variability in the data } \\
\text { for the main outcomes? In non-normally distributed data, the } \\
\text { interquartile range of results should be reported. In normally } \\
\text { distributed data the standard error, standard deviation or confidence } \\
\text { intervals should be reported }\end{array}$ & No & No & No & No \\
\hline 8 & $\begin{array}{l}\text { Have all important adverse events that may be a consequence of the } \\
\text { intervention been reported? This should be answered 'yes' if the } \\
\text { study demonstrates that there was a comprehensive attempt to } \\
\text { measure adverse events (complications but not an increase in pain) }\end{array}$ & No & No & No & No \\
\hline 9 & $\begin{array}{l}\text { Have the characteristics of patients lost to follow-up been described? If } \\
\text { not explicit = no. Retrospective }- \text { if not described = unable to } \\
\text { determine; if not explicit re: numbers agreeing to participate = no. } \\
\text { Needs to be }>85 \%\end{array}$ & $\begin{array}{l}\text { Unable to } \\
\text { determine }\end{array}$ & No & No & $\begin{array}{l}\text { Unable to } \\
\text { determine }\end{array}$ \\
\hline 10 & $\begin{array}{l}\text { Have actual probability values been reported (e.g., } 0.035 \text { rather than } \\
<0.05 \text { ) for the main outcomes except where the probability value is } \\
<0.001 \text { ? }\end{array}$ & Yes & Yes & Yes & No \\
\hline 11 & $\begin{array}{l}\text { Were the subjects asked to participate in the study representative of the } \\
\text { entire population from which they were recruited? The study must } \\
\text { identify the source population for patients and describe how the } \\
\text { patients were selected }\end{array}$ & Yes & $\begin{array}{l}\text { Unable to } \\
\text { determine }\end{array}$ & Yes & No \\
\hline 12 & $\begin{array}{l}\text { Were those subjects who were prepared to participate representative of } \\
\text { the entire population from which they were recruited? The } \\
\text { proportion of those participants invited to participate and who } \\
\text { agreed should be stated }\end{array}$ & No & $\begin{array}{l}\text { Unable to } \\
\text { determine }\end{array}$ & $\begin{array}{l}\text { Unable to } \\
\text { determine }\end{array}$ & $\begin{array}{l}\text { Unable to } \\
\text { determine }\end{array}$ \\
\hline 13 & $\begin{array}{l}\text { Were the staff, places and facilities where the participants were treated } \\
\text { representative of the treatment that the majority of patients receive? } \\
\text { For the question to be answered 'yes', the study should demonstrate } \\
\text { that the intervention was representative of that in use in the source } \\
\text { population. Must state type of hospital and country for 'yes' }\end{array}$ & Yes & $\begin{array}{l}\text { Unable to } \\
\text { determine }\end{array}$ & $\begin{array}{l}\text { Unable to } \\
\text { determine }\end{array}$ & $\begin{array}{l}\text { Unable to } \\
\text { determine }\end{array}$ \\
\hline 14 & $\begin{array}{l}\text { Was an attempt made to blind study subjects to the intervention they } \\
\text { have received? For studies where the patients would have no way of } \\
\text { knowing which intervention they received, this should be answered } \\
\text { 'yes'. Retrospective, single group = no; unable to determine if }>1 \\
\text { group and blinding not explicitly stated }\end{array}$ & No & No & No & No \\
\hline 15 & $\begin{array}{l}\text { Was an attempt made to blind those measuring the main outcomes of } \\
\text { the intervention? Must be explicit }\end{array}$ & No & No & No & No \\
\hline 16 & $\begin{array}{l}\text { If any of the results of the study were based on 'data dredging', was } \\
\text { this made clear? Any analyses that had not been planned at the } \\
\text { outset of the study should be clearly indicated. Retrospective = no; } \\
\text { prospective = yes }\end{array}$ & $\begin{array}{l}\text { Unable to } \\
\text { determine }\end{array}$ & $\begin{array}{l}\text { Unable to } \\
\text { determine }\end{array}$ & $\begin{array}{l}\text { Unable to } \\
\text { determine }\end{array}$ & $\begin{array}{l}\text { Unable to } \\
\text { determine }\end{array}$ \\
\hline 17 & $\begin{array}{l}\text { In trials and cohort studies, do the analyses adjust for different lengths } \\
\text { of follow-up of patients, or in case-control studies, is the time period } \\
\text { between the intervention and outcome the same for cases and } \\
\text { controls? Where follow-up was the same for all study patients the } \\
\text { answer should be 'yes'. Studies where differences in follow-up are } \\
\text { ignored should be answered 'no'. Acceptable range } 1 \text {-year follow-up } \\
=1 \text { month each way; } 2 \text {-year follow-up }=2 \text { months; } 3 \text {-year follow- } \\
\text { up }=3 \text { months...10-year follow up }=10 \text { months }\end{array}$ & $\begin{array}{l}\text { Unable to } \\
\text { determine }\end{array}$ & $\begin{array}{l}\text { Unable to } \\
\text { determine }\end{array}$ & No & No \\
\hline
\end{tabular}


Table A.5 (continued)

\begin{tabular}{|c|c|c|c|c|c|}
\hline & \multirow[b]{2}{*}{ Answers: yes, no, unable to determine } & \multicolumn{4}{|c|}{ Author, year, reference } \\
\hline & & $\begin{array}{l}\text { Balogun, } \\
2015^{18}\end{array}$ & $\begin{array}{c}\text { Wu, } \\
2009^{20}\end{array}$ & $\begin{array}{l}\text { Macq, } \\
2008^{17}\end{array}$ & $\begin{array}{c}\text { Croft, } \\
\text { 1999 }^{19}\end{array}$ \\
\hline 18 & $\begin{array}{l}\text { Were the statistical tests used to assess the main outcomes } \\
\text { appropriate? The statistical techniques used must be appropriate to } \\
\text { the data. If no tests were performed, but would have been } \\
\text { appropriate to do = no }\end{array}$ & Yes & Yes & $\begin{array}{l}\text { Unable to } \\
\text { determine }\end{array}$ & No \\
\hline 19 & $\begin{array}{l}\text { Was adherence to the intervention/s reliable? Where there was non- } \\
\text { adherence to the allocated treatment or where there was } \\
\text { contamination of one group, the question should be answered 'no'. } \\
\text { Surgical studies will be 'yes' unless the procedure was not completed }\end{array}$ & $\begin{array}{l}\text { Unable to } \\
\text { determine }\end{array}$ & $\begin{array}{l}\text { Unable to } \\
\text { determine }\end{array}$ & $\begin{array}{l}\text { Unable to } \\
\text { determine }\end{array}$ & $\begin{array}{l}\text { Unable to } \\
\text { determine }\end{array}$ \\
\hline $2^{\circ}$ & $\begin{array}{l}\text { Were the main outcome measures used accurate (valid and reliable)? } \\
\text { Where outcome measures are clearly described, which refer to other } \\
\text { work or that demonstrates the outcome measures are accurate = } \\
\text { yes. ALL primary outcomes valid and reliable for 'yes' }\end{array}$ & $\begin{array}{l}\text { Unable to } \\
\text { determine }\end{array}$ & Yes & Yes & $\begin{array}{l}\text { Unable to } \\
\text { determine }\end{array}$ \\
\hline 21 & $\begin{array}{l}\text { Were the patients in different intervention groups (trials and cohort } \\
\text { studies) or were the cases and controls (case-control studies) } \\
\text { recruited from the same population? Patients for all comparison } \\
\text { groups should be selected from the same hospital. The question } \\
\text { should be answered 'unable to determine' for cohort and case- } \\
\text { control studies where there is no information concerning the source } \\
\text { of patients }\end{array}$ & $\begin{array}{l}\text { Unable to } \\
\text { determine }\end{array}$ & $\begin{array}{l}\text { Unable to } \\
\text { determine }\end{array}$ & No & No \\
\hline 22 & $\begin{array}{l}\text { Were study subjects in different intervention groups (trials and cohort } \\
\text { studies) or were the cases and controls (case-control studies) } \\
\text { recruited over the same time? For a study which does not specify the } \\
\text { time period over which patients were recruited, the question should } \\
\text { be answered as 'unable to determine'. Surgical studies must be }<10 \\
\text { years for 'yes', if }>10 \text { years then 'no' }\end{array}$ & $\begin{array}{l}\text { Unable to } \\
\text { determine }\end{array}$ & $\begin{array}{l}\text { Unable to } \\
\text { determine }\end{array}$ & Yes & Yes \\
\hline 23 & $\begin{array}{l}\text { Were study subjects randomised to intervention groups? Studies which } \\
\text { state that subjects were randomised should be answered 'yes', } \\
\text { except where method of randomisation would not ensure random } \\
\text { allocation }\end{array}$ & $\begin{array}{l}\text { Unable to } \\
\text { determine }\end{array}$ & $\begin{array}{l}\text { Unable to } \\
\text { determine }\end{array}$ & No & No \\
\hline 24 & $\begin{array}{l}\text { Was the randomised intervention assignment concealed from both } \\
\text { patients and health care staff until recruitment was complete and } \\
\text { irrevocable? All non-randomised studies should be answered 'no'. If } \\
\text { assignment was concealed from patients but not from staff, it should } \\
\text { be answered 'no' }\end{array}$ & $\begin{array}{l}\text { Unable to } \\
\text { determine }\end{array}$ & $\begin{array}{l}\text { Unable to } \\
\text { determine }\end{array}$ & No & $\begin{array}{l}\text { Unable to } \\
\text { determine }\end{array}$ \\
\hline 25 & $\begin{array}{l}\text { Was there adequate adjustment for confounding in the analyses from } \\
\text { which the main findings were drawn? In non-randomised studies, if } \\
\text { the effect of the main confounders was not investigated or no } \\
\text { adjustment was made in the final analyses the question should be } \\
\text { answered 'no'. If no significant difference between groups shown, } \\
\text { then 'yes' }\end{array}$ & $\begin{array}{l}\text { Unable to } \\
\text { determine }\end{array}$ & Yes & Yes & No \\
\hline 26 & $\begin{array}{l}\text { Were losses of patients to follow-up taken into account? If the numbers } \\
\text { of patients lost to follow-up are not reported = unable to determine }\end{array}$ & $\begin{array}{l}\text { Unable to } \\
\text { determine }\end{array}$ & No & No & $\begin{array}{l}\text { Unable to } \\
\text { determine }\end{array}$ \\
\hline \multirow[t]{2}{*}{27} & $\begin{array}{l}\text { Did the study have sufficient power to detect a clinically important } \\
\text { effect where the probability value for a difference being due to } \\
\text { chance }<5 \% \text {. Sample sizes have been calculated to detect a } \\
\text { difference of } x \% \text { and } y \% \text {. }\end{array}$ & Yes & $\begin{array}{l}\text { Unable to } \\
\text { determine }\end{array}$ & $\begin{array}{l}\text { Unable to } \\
\text { determine }\end{array}$ & $\begin{array}{l}\text { Unable to } \\
\text { determine }\end{array}$ \\
\hline & Score (number of 'Yes' answers) & 11 & 9 & 11 & 7 \\
\hline
\end{tabular}


Table A.6 Qualitative framework used by Spencer et al.*

\begin{tabular}{|c|c|}
\hline 1 & How credible are the findings? \\
\hline 2 & How has knowledge/understanding been extended by the research? \\
\hline 3 & How well does the evaluation address its original aims and purpose? \\
\hline 4 & Scope for drawing wider inference-how well is this explained? \\
\hline 5 & How clear is the basis of the evaluative appraisal? \\
\hline 6 & How defendable is the research design? \\
\hline 7 & How well defended is the sample design/target selection of cases/document? \\
\hline 8 & Sample composition/case inclusion-how well is the eventual coverage described? \\
\hline 9 & How well was the data collection carried out? \\
\hline 10 & How well has the approach to, and the formulation of, the analysis been conveyed? \\
\hline 11 & Contexts of data sources-how well are they portrayed? \\
\hline 12 & How well has the diversity of perspective and content been explored? \\
\hline 13 & How well has detail, depth and complexity (i.e., richness) of the data been conveyed? \\
\hline 14 & $\begin{array}{l}\text { How clear are the links between data, interpretation and conclusions, i.e., how well can the } \\
\text { route to any conclusions be seen? }\end{array}$ \\
\hline 15 & How clear and coherent is the reporting? \\
\hline 16 & $\begin{array}{l}\text { How clear are the assumptions/theoretical perspectives/values the have shaped the form and } \\
\text { output of the evaluation? }\end{array}$ \\
\hline 1 & What evidence is there to attention of ethical issues? \\
\hline 18 & How adequately has the research process been documented? \\
\hline
\end{tabular}

* Based on reference 9

Table A.7 Spencer et al. framework scores*

\begin{tabular}{|c|c|c|c|c|c|c|}
\hline & Chalco, $2006^{16}$ & Score & Acha, $2007^{15}$ & Score & Demissie, $2003^{4}$ & Score \\
\hline 1 & Moderate confidence & 2 & Moderate confidence & 2 & Moderate confidence & 2 \\
\hline 2 & Low confidence & 1 & Moderate confidence & 2 & Moderate confidence & 2 \\
\hline 3 & Moderate confidence & 2 & Moderate confidence & 2 & High confidence & 3 \\
\hline 4 & Moderate confidence & 2 & Low confidence & 1 & Moderate confidence & 2 \\
\hline 5 & Low confidence & 1 & Low confidence & 1 & Low confidence & 1 \\
\hline 6 & High confidence & 3 & High confidence & 3 & High confidence & 3 \\
\hline 7 & Low confidence & 1 & Moderate confidence & 2 & Moderate confidence & 2 \\
\hline 8 & Very low confidence & 0 & Moderate confidence & 2 & Low confidence & 1 \\
\hline 9 & Moderate confidence & 2 & High confidence & 3 & Moderate confidence & 2 \\
\hline 10 & Moderate confidence & 2 & Moderate confidence & 2 & Low confidence & 1 \\
\hline 11 & Low confidence & 1 & Moderate confidence & 2 & Moderate confidence & 2 \\
\hline 12 & Low confidence & 1 & Moderate confidence & 2 & Low confidence & 1 \\
\hline 13 & Low confidence & 1 & Moderate confidence & 2 & Moderate confidence & 2 \\
\hline 14 & Moderate confidence & 2 & High confidence & 3 & High confidence & 3 \\
\hline 15 & Moderate confidence & 2 & High confidence & 3 & Moderate confidence & 2 \\
\hline 16 & Low confidence & 1 & Low confidence & 1 & Moderate confidence & 2 \\
\hline 17 & Moderate confidence & 2 & Very low confidence & 0 & Low confidence & 1 \\
\hline \multirow[t]{2}{*}{18} & Very low confidence & 0 & Moderate confidence & 2 & Moderate confidence & 2 \\
\hline & & 26 & & 35 & & 34 \\
\hline
\end{tabular}

* Based on reference 9 .

\section{References}

1 Chalco K, Wu D, Mestanza L, et al. Nurses as providers of emotional support to patients with MDR-TB. Int Nurs Rev 2006; 53: 253-260.

2 Dick J, Lewin S, Rose E, Zwarenstein M, van der Walt $\mathrm{H}$. Changing professional practice in tuberculosis care: an educational intervention. J Adv Nurs 2004; 48: 434-442.

3 Karels M, Jansen E. Community involvement in raising awareness about TB among Somalian population. The Hague, The Netherlands: KNCV Tuberculosis Foundation, GGD Hollands Noorden, 2014.

4 Liefooghe R, Suetens C, Meulemans H, Moran M B, De Muynck A. A randomised trial of the impact of counselling on treatment adherence of tuberculosis patients in Sialkot, Pakistan. Int Tuberc Lung Dis 1999; 3: 1073-1080.

5 Machmud R H D, Thompson M, Mukhtar M. Involving school children and multisector approach as strategies to reduce the stigma of TB in Indonesia. Am J Respir Crit Care 2015; 191: A2227.
6 Mohammed S S, Sana Z, Khan F S. Harnessing Photovoice for tuberculosis advocacy in Karachi, Pakistan. Health Promotion Int 2015; 30: 262-269.

7 Moya E M C B, Silvia M, Wood W W, Martínez O. A project to reduce inequalities and tuberculosis along the US-Mexico border. In: Friedman B D M J, Friedman B D, Merrick J, eds. Public health, social work and health inequalities. Public health: practices, methods and policies. Hauppauge, NY, USA: Nova Science Publishers, 2015: pp 15-31.

8 Unmask Stigma. Summary: \#UnmaskStigma-global initiative to break down stigma related to tuberculosis. Geneva, Switzerland: Unmask Stigma, 2015 http://www.unmaskstigma. org/. Accessed July 2017.

9 Spencer L, Ritchie J, Lewis J, Dillon L. Quality in qualitive evaluation: a framework for assessing research evidence. London, UK: UK Government Chief Social Researcher's Office, 2003. 
CONTEXTE : Bien qu'il y ait des progrès substantiels en matière de lutte contre la tuberculose (TB), le succès des efforts de santé publique est entravé par une stigmatisation généralisée.

OBJECTIF : Réaliser une revue systématique de la littérature afin d'évaluer l'efficacité des interventions visant à réduire la stigmatisation liée à la TB parmi les patients, le personnel de santé, les aidants et la communauté dans son ensemble.

SCHÉMA : Les études ont été éligibles pour leur inclusion si elles avaient évalué des interventions visant à réduire la stigmatisation liée à la TB et si elles avaient été publiées entre 1950 et 2015 . Nous avons fait des recherches dans huit bases de données (PubMed, Cochrane Library, Ovid, Embase, PsycInfo, Sociological Abstracts, Cumulative Index to Nursing and Allied Health Literature et World Health Organization Latin American and Caribbean Health Sciences Literature) et complété les recherches en utilisant la stratégie de la boule de neige et en revoyant la littérature grise pertinente.

RÉSULTATS : Seules sept études ont été identifiées car elles ont mis en évidence des preuves quantitatives ( $n=$ $4)$ ou qualitatives $(n=3)$ de leur efficacité en matière de réduction de la stigmatisation liée à la TB. L'évaluation de la qualité des études a été médiocre. Les interventions de modification des connaissances et de changement d'attitude destinées au public, aux patients et à leurs familles ont été efficaces en termes de réduction de la stigmatisation anticipée. Les visites à domicile et les groupes de soutien ont été efficaces en réduisant à la fois la stigmatisation anticipée et internalisée.

CONCLUSION : Il y a une pénurie d'informations fiables relatives à l'efficacité des interventions de réduction de la stigmatisation liée à la TB. Les interventions de modification des connaissances, de changement d'attitude et de soutien au patient peuvent être efficaces en réduisant la stigmatisation liée à la TB, mais des évaluations plus rigoureuses sont nécessaires.
MARCO DE REFERENCIA: Pese a los progresos considerables alcanzados en el control de la tuberculosis (TB), la ubicuidad de la estigmatización obstaculiza los esfuerzos de salud pública.

O B JETIV O: Llevar a cabo una revisión sistemática de las publicaciones científicas con el objeto de evaluar la eficacia real de las intervenciones encaminadas a disminuir la estigmatización asociada con la TB en los pacientes, los profesionales de salud, los cuidadores y la comunidad en general.

MÉTODO: Se consideraron idóneos los estudios que evaluaban intervenciones cuyo objeto era disminuir la estigmatización generada por la TB, publicados entre 1950 y 2015 . La búsqueda se llevó a cabo en ocho bases de datos (PubMed, Cochrane Library, Ovid, Embase, PsycInfo, Sociological Abstracts, el Cumulative Index to Nursing and Allied Health Literature and el Latin American and Caribbean Health Sciences Literature de la Organización Mundial de la Salud) y se complementó mediante la estrategia en bola de nieve y un análisis de la literatura gris pertinente.
RESULTADOS: Se encontraron solo siete estudios, los cuales comunicaban pruebas de eficacia real cuantitativa $(n=4)$ o cualitativa $(n=3)$ en materia de reducción de la estigmatización asociada con la TB. La evaluación de la calidad de los estudios era deficiente. Las intervenciones de adecuación de los conocimientos y modificación de las actitudes dirigidas al público, los pacientes y a sus familias fueron eficaces para disminuir la estigmatización. Las visitas domiciliarias y los grupos de apoyo lograron reducir los estigmas anticipados y también los estigmas internalizados.

CONCLUSIÓN: Se confirmó la carencia de información fiable con relación a la eficacia práctica de las intervenciones encaminadas a disminuir la estigmatización asociada con la TB. Las intervenciones de adecuación de los conocimientos, modificación de las actitudes y apoyo a los pacientes pueden ser eficaces con este fin, pero es necesario realizar evaluaciones más rigurosas. 